\title{
Individualism and Collectivism Culture to Audit Judgement
}

\author{
Submitted on $4 / 01 / 19,1^{\text {st }}$ revision $18 / 1 / 19,2^{\text {nd }}$ revision $22 / 2 / 19$ accepted $08 / 04 / 19$
}

Tulus Suryanto ${ }^{1}$, Danial Thaib ${ }^{2}$, Muliyati Muliyati ${ }^{3}$

\begin{abstract}
:
Purpose: This paper is to survey and examine the impact of individualism and collectivism culture on audit judgement in Central Java Provinces, Indonesia. The paper intents to audit judgement and factors influencing audit judgement, using survey data collected by the authors. Design/Methodology/Approach: The study uses the cultural dimensions of individualism/collectivism with cultural variables consisting of individualism and collectivism culture on audit judgment at Public Accounting Firm. The data set is from senior auditors in Central Java Provinces, Indonesia, which perhaps limits its usefulness elsewhere.

Findings: The paper found that most of the respondents who have individualistic culture are not supportive to audit judgement, while respondents who have collectivistic culture are supportive to audit judgement.

Practical Imlpications: The paper will help auditors, accountants, and policy makers to consider individualistic and collectivistic culture on audit judgement.

Originality/Value: The paper uses original survey data collected by the author who has considered individualism and collectivism in the analysis to enable policy makers to consider individualism and collectivism on audit judgements.
\end{abstract}

Keywords: Individualism culture, collectivism culture, audit judgement, senior auditor.

JEL code: $M 42$, M48.

Paper type: Research article.

${ }^{1}$ Universitas Negeri Islam, Raden, Lampung, Indonesia,e-mail: tulus@radenintan.ac.id

${ }^{2}$ Fakultas Ekonomi Management Institut Bisnis dan Informatika Kosgoro 1957, Jakarta Indonesia,e-mail: danialthaib@gmail.com

${ }^{3}$ Fakultas Ekonomi Management Institut Bisnis dan Informatika Kosgoro 1957, Jakarta Indonesia, e-mail: muliyati@bisnis.ac.id 


\section{Introduction}

Judgement audit is an important step in the audit process, because the final result of audit process that strongly affects an auditor's opinion is the judgment audit step. Research on judgment audits has been widely conducted by Wright and Wright (1997) who argued that an auditor may consider revising audit decisions as they evaluate audit findings and find audit error detection. Tubbs et al. (1990) suggested several conditions which greatly affect judgment audits such as excess of assets and reduction of responsibility.

Hofstede $(1980 ; 1991)$ revealed that one of the dominant factors capable of influencing a person in making decisions is cultural factors. Hofstede's $(1980 ; 1991)$ statement followed by a research conducted by Hogarth and Einhorn (1992) using cultural variables as factors influencing someone to provide additional information in the audit process, indicated that culture is a very influential factor in an individual's decision to decide whether he or she should provide additional information in the audit process (Jindrichovska and Kubickova, 2016).

The national cultural effect on audit judgement is considered important for three reasons. First, as globalization emerges, the company feel that they need to establish an international operation. The question of whether a local audit firm can run an audit and a risk assessment brings about practical significance.

Second, because there are different cultures, it is not always clear whether the sent message has the same content as the received message. Equation of meaning is a necessary condition for effective communication (Osgood et al., 1957; Johnson, 1977), since communication often exceeds the expected limit, messages received in a country may have different meanings due to cross-cultural differences (Bagranoff, 1990; Suryanto et al., 2017; Grima et al., 2017).

Third, International Standard on Auditing (ISA 400, par. 38, 2003) on audit risk assessment requires group consultation. (ISA 220, par. 14, 2003) on the quality control of audit work stated that professional judgment differences among personnel can be resolved through appropriate consultations. With globalization, some countries use international accounting and auditing standards. However, the way in which countries use and apply standards may differ because of national culture (Suryanto and Thalassinos, 2017; Amilin, 2017).

The study uses the cultural dimensions of individualism/collectivism proposed by Hofstede $(1980 ; 1991)$. The study is a follow up of the research conducted by Sim et al. (2004) who examined the cultural effects on group decision making in eastern and western cultures. In this study we used national cultural variables consisting of individualism and collectivism culture on audit judgment at KAP (Public Accounting Firm) in Central Java Province. 


\section{Theoretical Basis and Hypothesis}

\subsection{Cultural impact on judgement audit}

Hofstede (1980) defines culture as a collective mental programming that distinguishes one group from another. This programming contains social values and beliefs. Values are the tendency of individuals to like certain conditions than others. Hofstede presents four different work-related values between cultures, namely IndividualismCollectivism, Power Distance, Uncertain Avoidance, and Masculinity-Femininity. Subsequent research reported by Hofstede and Bond (1988) suggests the fifth cultural dimension, called Confucian Dynamism.

In the context of judgement audit, the effects of national culture tend to have an impact on how to conduct audit planning. Individual culture refers to the extent to which individuals are integrated into organizations or institutions, whereas collectivism refers to individuals acting as members of a group (Hofstede, 2001).

In individualist cultures, group members prefer open and direct communication channels in resolving conflicts. When an individualist audit group must make a final decision on audit risk, the dimension of individualism, which contains values associated with stimulation and intellectual autonomy, can have a certain impact. Therefore, group members should make more persuasive arguments, so the group makes more revisions when there are issues to be solved. Conditions are often found in situations where new supplemental evidence is relatively unlikely compared to initial information. The individualist attitude tends to avoid the risk of "shame" if someone makes a mistake, because the attitude of individualism considers "learning is the learning process from failure."

In contrast, collectivist culture always tries to keep the rhythm, collectivistic auditors try to maintain harmony and strengthen consensus by creating the majority. Shame is used as a mechanism to express mistakes (Triandis et al., 1988). Due to the fear of losing "face" and embarrassment that the audit could lead to litigation of audit firms, auditors in collectivist cultures tend to choose "safer approaches". They expect their beliefs to be adjusted by increasing the budget amount of the audit hour. Because of fear of losing "face", there is less persuasive argument than group members and the failure to educate each member in the group. Consequently, they tend to perceive that the audit risk is high. Precisely, the collectivistic cultural auditor is very sensitive to negative evidence compared to individualistic cultural auditors.

On the other hand, collectivistic cultural auditors rarely want to revise their beliefs by reducing the budget number of audit hours when new pieces of evidence are received, which the new piece is favored rather than the very unlikely initial information. This result is caused by the fear of "losing face" when confronted with the first piece of information that is very unpopular. The unwillingness of reducing the clock budget reflects a strong "face" on the part of the audit firm. A strong obedient tendency makes 
audit firms more cooperative than resisting, and avoidance is always considered "different". Based on the above explanation we can state the research hypotheses as follows:

H1: Individualistic culture has a positively effect on audit judgement;

H2: Collectivistic culture has a positive effect on audit judgement.

\section{Research methodology}

The population of this study is public accounting firms in Central Java Province, while the sample consisting of senior auditors from these firms. The reason for choosing senior auditors is because the senior auditor is more responsible for the decision in the audit process. Data collection was conducted by mail survey through questionnaires distributed directly to sample areas (personally administered questionnaire). The questionnaire form consists of related questions (structured questionnaire). This data is obtained through questionnaires distributed to each respondent by random sampling technique. Respondents answered the question posed on the questionnaire and selected the most appropriate of the various alternative answers provided without having the option to provide another answer, the questionnaire of this form is more attractive to the respondent because of its ease in providing answers and also the time spent to answer the questions is shorter.

\subsection{Definition of operational variables and research instruments}

Individualism culture tends to be related to modern culture. The individualist attitude tends not to risk the "shame" if someone makes a mistake, because the attitude of individualism considers "learning is the learning process from failure". Cultural collectivism is measured by five development indicators from Hofstede (1991) measured by the Likert scale with range $1=$ strongly disagree up to $5=$ strongly agree. Culture of collectivism always try to keep the rhythm; collectivist auditors try to maintain harmony and strengthen consensus by creating the majority. Shame is used as a mechanism to express mistakes (Triandis et al., 1988). Cultural collectivism is measured by six development indicators from Hofstede (1991), and Godfellow (2002) measured by the Likert scale with range $1=$ strongly disagree to $5=$ strongly agree.

Judgment audit is a process of consideration or an auditor's perspective in responding to information relating to the risks and responsibilities faced by the auditor and influencing opinion making (Jusuf, 2012). Audit judgement measurement adopted from research conducted by Puspitasari (2014) with five indicators with the Likert scale with range $1=$ strongly disagree to $5=$ strongly agree.

\subsection{Data Quality Test}

There are two procedures performed for reliability and validity, namely; internal consistency test of respondents' answers on research instruments and the validity test 
of constructs by correlating the score of each item with the total score. Description of the two data quality tests are as follows:

$>$ Internal consistency test (reliability) is determined by coefficient of Cronbach alpha. A construct or instrument is said to be reliable if it gives a Cronbach alpha value above 0.60 (Hair, 1995);

$>$ Test data homogeneity (validity) with Pearson's correlation test. If the result is significant then the data is said to be valid.

\subsection{Classical assumption test}

Before the multiple linear regression analysis was done, the classical assumption test is first performed. The regression model derived from the Ordinary Least Squares method is a regression model that produces the best non-biased linear estimator (BLUE/Best Linear Unbias Estimator) (Suliyanto, 2005). These conditions will occur if they meet all the classical assumptions such as:

\section{a. Normality test:}

This test aims to determine whether the data under study is normally distributed or not. One way to test the normality is to use Kolmogorov-Smirnov test against the residual standard value of the regression equation. When the sample KolmogorovSmirnov test is greater than the significant level used $(\alpha=0.05)$, then the distribution of data spreads normally.

\section{b. Multicollinearity test:}

This test is used to determine whether in the regression model found a high or perfect correlation between the variables. If the independent variables are perfectly correlated, then the resulting regression equation cannot be used. The most commonly used statistical tool for testing multicollinearity disorders is either the tolerance or VIF (Variance Inflation Factor) value used to detect the presence of multicollinearity. The tolerance value limit is $>0.10$ and VIF $<10$ (Suliyanto, 2011). If the tolerance value is below 0.10 or VIF value above 10 then it can be assured that multicollinearity has occurred.

\section{c. Heteroscedasticity test:}

This test is used to determine whether in the regression model there is a variance inequality of the residual of one observation to another observation. The heteroscedasticity test is done by looking at the plot graph, where if the plot graph is spreading and not forming the pattern it is concluded that there is no heteroscedasticity (Ghozali, 2005).

\subsection{Hypothesis testing}

Two ways test analysis of variance and main effects are used to see the effect of categories of independent variables that are more than 1 . The result of this test will be 
seen from the significance value of the test of between the variables-subject effect, where if $p<0.005$ then it is certain that there is influence between the independent variable and the dependent variable. On the contrary if the result of significance shows value greater than 0.005 or $\mathrm{p}>0.005$ then it is certain that there is not influence between the independent and the dependent variable (Ghozali, 2015).

\section{Results and Discussion}

Characteristics of respondents by gender are grouped into female respondents and male respondents. Table 1 presents the characteristics of respondents by gender:

Table 1. Overview of respondents by gender

\begin{tabular}{lll}
\hline Gender & Number (People) & Percentage $(\boldsymbol{\%})$ \\
\hline Male & 28 & 58 \\
Female & 20 & 42 \\
\hline Total & 48 & 100 \\
\hline
\end{tabular}

Source: Primary data processed, 2018.

Table 1 shows that most of respondents were male (28) or 58\%, while female (22) or $42 \%$. Characteristics of respondents by age grouped into three categories of respondents whose age $\leq 25$ years, $25-40$ years, and $\geq 40$ years. Table 2 presents these characteristics:

Table 2. Overview of respondents by age

\begin{tabular}{|c|c|c|}
\hline Age (years) & Number (People) & Percentage (\%) \\
\hline$\leq 25$ & 10 & 21 \\
\hline $25-40$ & 28 & 58 \\
\hline$\geq 40$ & 10 & 21 \\
\hline Total & 48 & 100 \\
\hline
\end{tabular}

Source: Primary data processed, 2018.

Table 2 shows that most of the study respondents were aged between 25-40 years. Table 3 shows that most the respondents have undergraduate education, 23 persons or $47.9 \%, 10$ are educated in $\mathrm{S} 2$ or $20.8 \%$, and 15 have diploma or $32.2 \%$.

Table 3. Overview of respondents by education

\begin{tabular}{lll}
\hline Education & Number (People) & Percentage (\%) \\
\hline Diploma & 15 & 32,2
\end{tabular}




\begin{tabular}{lll}
$\mathrm{S} 1$ & 23 & 47,9 \\
$\mathrm{~S} 2$ & 10 & 20,8 \\
\hline Total & 48 & 100,00 \\
\hline
\end{tabular}

Source: Primary data processed, 2018.

\subsection{Data Quality Test}

a. Reliability and Validity Test Results:

Based on the test data quality data is feasible to be analyzed to the next stage. Tables 4 and 5 present the results of the reliability and validity of data.

Table 4. Reliability test

\begin{tabular}{|l|l|l|l|}
\hline No & Variable & $\begin{array}{l}\text { Cronbach } \\
\text { Alpha Value }\end{array}$ & Result \\
\hline 1 & Individualism culture & 0,877 & Reliable \\
\hline 2 & Collectivism culture & 0,907 & Reliable \\
\hline 3 & Audit judgement & 0,839 & Reliable \\
\hline
\end{tabular}

Source: Data processed, 2018.

Table 5. Validity test

\begin{tabular}{|l|l|l|l|l|}
\hline No & Variable & Correlation & $\begin{array}{l}\text { Significatio } \\
\mathbf{n}\end{array}$ & Result \\
\hline 1 & Individualism culture & $0.741^{* *}-0.850^{* *}$ & 0.01 & Valid \\
\hline 2 & Collectivism culture & $0.435^{* *}-0.928^{* *}$ & 0.01 & Valid \\
\hline 3 & Audit judgement & $0.525^{* *}-0.847^{* *}$ & 0.01 & Valid \\
\hline
\end{tabular}

Source: Data processed, 2018.

\subsection{Classical Assumption Test Results}

\section{a. Normality test results:}

The normality test method used is Kolmogorov-Smirnov. Normality test results can be seen in the following Table 6:

Based on Table 6 the normality test results of all normal distributed variables have significance value greater than 0.05 . Thus, it can be concluded all variables are normally distributed. 
Table 6. Results of normality test of data

One-Sample Kolmogorov-Smirnov Test

\begin{tabular}{|ll|l|}
\hline & & $\begin{array}{l}\text { Unstandardized } \\
\text { Residual }\end{array}$ \\
\hline $\mathrm{N}$ & & 48 \\
Normal Parameters ${ }^{\mathrm{a}, \mathrm{b}}$ & Mean & .0000000 \\
& Std. Deviation & 4.34902535 \\
Most Extreme Differences & Absolute & .091 \\
& Positive & .058 \\
Kolmogorov-Smirnov Z & Negative & -.091 \\
Asymp. Sig. (2-tailed) & & .631 \\
\hline
\end{tabular}

a. Test distribution is Normal.

b. Calculated from data.

Source: Data processed, 2018.

\section{b. Multicollinearity test results:}

Table 7 presents the multicollinearity test results. Based on the test results the VIF value in each variable is less than 10 and the tolerance value is less than 1 , so it is stated that all the independent variables are clean form multicollinearity symptoms.

Table 7. Multicollinearity test results

Coefficients $^{\mathbf{a}, \mathbf{b}}$

\begin{tabular}{|c|c|c|c|c|c|c|c|}
\hline \multirow[b]{2}{*}{ Model } & \multicolumn{2}{|c|}{$\begin{array}{l}\text { Unstandardized } \\
\text { Coefficients }\end{array}$} & \multirow{2}{*}{$\begin{array}{l}\text { Standardize } \\
\mathrm{d} \\
\text { Coefficient } \\
\mathrm{s} \\
\text { Beta }\end{array}$} & \multirow[b]{2}{*}{$\mathrm{t}$} & \multirow[b]{2}{*}{ Sig. } & \multicolumn{2}{|c|}{$\begin{array}{l}\text { Collinearity } \\
\text { Statistics }\end{array}$} \\
\hline & B & Std. Error & & & & $\begin{array}{l}\text { Toleran } \\
\text { ce }\end{array}$ & VIF \\
\hline 1 (Constant) & 22.802 & 4.576 & & 4.983 & .000 & & \\
\hline total_individualism & -.099 & .153 & -.093 & -.647 & .521 & .996 & 1.004 \\
\hline total_collectivism & .294 & .160 & .264 & 1.836 & .073 & .996 & 1.004 \\
\hline
\end{tabular}

a. Dependent Variable: total_judge 


\section{Coefficients $^{\mathbf{a}, \mathbf{b}}$}

\begin{tabular}{|c|c|c|c|c|c|c|c|}
\hline \multirow[b]{2}{*}{ Model } & \multicolumn{2}{|c|}{$\begin{array}{l}\text { Unstandardized } \\
\text { Coefficients }\end{array}$} & \multirow{2}{*}{$\begin{array}{l}\text { Standardize } \\
\mathrm{d} \\
\text { Coefficient } \\
\mathrm{s} \\
\text { Beta }\end{array}$} & \multirow[b]{2}{*}{$\mathrm{t}$} & \multirow[b]{2}{*}{ Sig. } & \multicolumn{2}{|c|}{$\begin{array}{l}\text { Collinearity } \\
\text { Statistics }\end{array}$} \\
\hline & B & Std. Error & & & & $\begin{array}{l}\text { Toleran } \\
\text { ce }\end{array}$ & VIF \\
\hline 1 (Constant) & 22.802 & 4.576 & & 4.983 & .000 & & \\
\hline total_individualism & -.099 & .153 & -.093 & -.647 & .521 & .996 & 1.004 \\
\hline
\end{tabular}

b. Weighted Least Squares Regression - Weighted by individu1

Source: Data processed, 2018.

c. Heteroskedasticity test results:

The following heteroskedasticity test results using SPSS program are presented in Figure1.

Figure 1. Scatter Plot heterokedisity test results

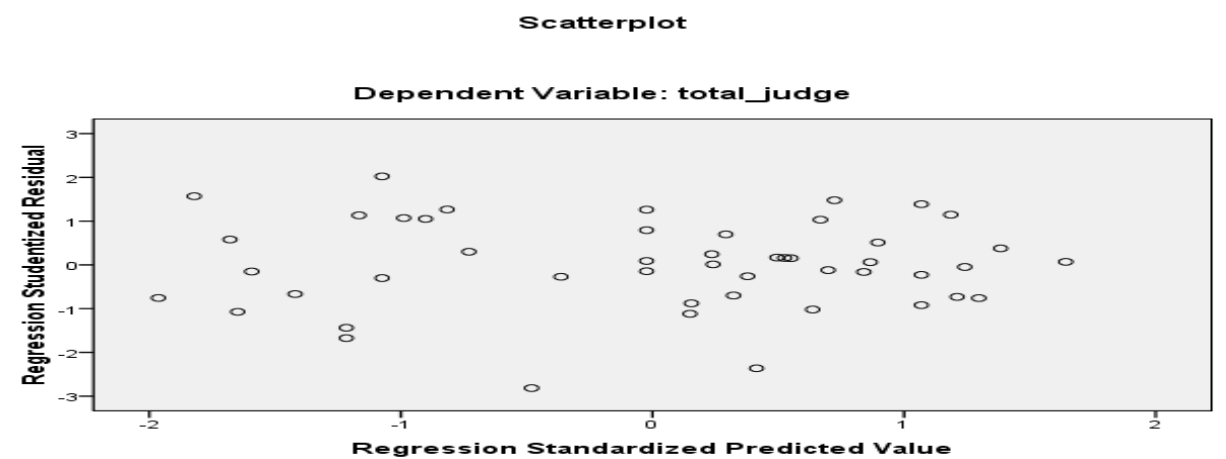

Source: Data processed, 2018.

The heteroskedasticity test was performed to test whether in the regression model there was a variance inequality of the residual from one observation to the other. If the variant of the other residual observations remains, then it is called homoskedasticity. A good regression model is homoskedastic or not heteroskedastic (Imam, 2002). Detection of whether heteroskedasticity is present is done by looking at the presence or absence of certain patterns (wavy, widened and narrowed) on the plot graph (scatterplot) between the predictive value of variables associated with its residuals. 
Based on the results of the graph plot (scatterplot) above (Figure 1) that there is no pattern (wavy, widened and narrowed), it can be interpreted that there is no heteroskedasticity on the regression model.

\subsection{Hypothesis testing}

\section{a. Levene's test of equality error variance test results:}

Before stepping into the test of two ways analysis of variance and main effects then we do first the Levene's Test of Equality Error Variance to see if there are differences in variance shown in Table 8 .

Table 8. Levene's test result of equality error variance

Dependent Variable: total_judge

\begin{tabular}{|l|l|l|l|}
\hline F & df1 & df2 & Sig. \\
\hline .823 & 40 & 7 & .683 \\
\hline
\end{tabular}

Tests the null hypothesis that the error variance of the dependent variable is equal across groups.

a. Design: Intercept + total_individualism + total_collectivism

Source: Data processed, 2018.

Levene's test of equality error variance shows that there is no difference in the variance between variables, because the $F$ value of 0.823 is statistically insignificant $(p=0.683)$ which means the non-rejected the null hypothesis (qualify assumption of ANOVA)

\section{b. Two ways analysis test of variance and main effects:}

To know the influence of cultural individualism (X1), and collectivism culture (X2) on judgment we used two ways analysis of variance and main effects test by using significance level $\mathrm{p}=<0.005$. Table 9 presents the results.

Table 9. Two ways analysis test results of variance

Tests of Between-Subjects Effects

Dependent Variable: total_judge

\begin{tabular}{|l|l|l|l|l|l|}
\hline Source & $\begin{array}{l}\text { Type III Sum } \\
\text { of Squares }\end{array}$ & Df & Mean Square & F & Sig. \\
\hline Corrected Model & $621.913^{\mathrm{a}}$ & 22 & 28.269 & 2.072 & .040 \\
Intercept & 9937.455 & 1 & 9937.455 & 728.412 & .000 \\
total_individualism & 211.943 & 13 & 16.303 & 1.195 & .338 \\
total_collectivism & 324.657 & 9 & 36.073 & 2.644 & .002
\end{tabular}


Tests of Between-Subjects Effects

Dependent Variable: total_judge

\begin{tabular}{|l|l|l|l|l|l|}
\hline Source & $\begin{array}{l}\text { Type III Sum } \\
\text { of Squares }\end{array}$ & Df & Mean Square & F & Sig. \\
\hline Corrected Model & $621.913^{\mathrm{a}}$ & 22 & 28.269 & 2.072 & .040 \\
Intercept & 9937.455 & 1 & 9937.455 & 728.412 & .000 \\
Error & 341.066 & 25 & 13.643 & & \\
Total & 37649.000 & 48 & & & \\
Corrected Total & 962.979 & 47 & & & \\
\hline
\end{tabular}

a. R Squared $=.646$ (Adjusted R Squared $=.334)$

Source: Data processed, 2018.

Two ways analysis of variance and main effects (ANOVA) test results show that the F value of cultural variables of individualism is 1.195 with significance level $p=0.338$ (well above 0.005). These results indicate that there is no influence between individualism culture on audit judgment, so it is concluded that hypothesis 1 which states culture of individualism positively influence on judgment audit, is rejected.

For test result of collectivism variable show $\mathrm{F}$ equal to 2,644 with significance value $\mathrm{p}=0.002$ indicating that there is influence between collectivism culture to audit judgment or in other words hypothesis expressing culture of collectivism have positive effect to audit judgment, therefore it is accepted.

\section{c. Individualistic culture has a positive effect on judgment audit:}

It is known that individualistic culture is proven to affect negatively the judgment audit. The results of this study are different from the research conducted by Hofstede (2001). The result of this difference is due to the tendency of respondents which are senior level auditors with more than three years of experience. Enough experience makes the respondents to behave more wisely, not being individualistic in the audit work process in their team. The facts on the ground also show that respondents tend to be cautious in making decisions, they are not reckless in deciding something especially related to audit decisions. The concept of caution and avoidance of shame is important to improve their image in the society.

\section{d. Collectivistic culture has a positive effect on judgment audit:}

It is known that collectivistic culture has positive effect to judgment audit. The results of this research support the research undertaken by Hofstede (2001) and Godfellow (2002). The senior auditors sampled in this study always try to keep the rhythm, senior auditors maintain harmony and strengthen consensus by creating a majority against other team members in deciding things. Sharing information resources is very important in the team. 


\section{Conclusions}

The individualistic culture has been shown to negatively affect the judgment of the audit. The results of this study are different from the research conducted by Hofstede (2001). The collectivistic culture has a positive effect on audit judgment. The results support the research undertaken by Hofstede (2001) and Godfellow (2002).

The sample of this study consists of senior auditors so results with a wider scope cannot be obtained. Future research is expected to add categories until both senior auditors, junior and direct leaders to be included in the sample. Also future research needs to add different cultural views in order to improve the generality of the findings.

\section{References:}

Amilin, A. 2017. The Impact of Role Conflict and Role Ambiguity on Accountants' Performance: The Moderating Effect of emotional Quotient. European Research Studies Journal, 20(2A), 237-249.

Asare, S.K., Messier, W.F. 1991. A review of audit research using the Belief -Adjustment Model. In: L. Ponemon and C.R. Gebhart, Auditing: Advances in Behavioral Research. New York, Springer-Verlag, 111-135.

Ashton, A.H., Ashton, R.H. 1988. Sequential belief revision in auditing. The accounting Review, 63(4), 623-641.

Bagranoff, N.A. 1990. The semantic differential: a prescription for use in accounting research. Journal of Accounting Literature, 19, 65-80.

Bagranoff, N.A. 1994. The structure of meaning in Accounting: a cross-cultural experiment. Behavioural Research in Accounting 6 (Supplement), 35-60.

Baldacchino, J.P., Camilleri, C., Grima, S., Bezzina, H.F. 2017. Assessing Incentive and Monitoring Schemes in the Corporate Governance of Maltese Co-operatives. European Research Studies Journal, 20(3A), 179-197.

Child, J. 1981. Culture, Contingency and capitalism in the cross-national study of organizations. Research in Organisational Behaviour, 303-356.

Chinese Culture Connection. 1987. Chinese values and the search for culture-free dimensions of culture. Journal of Cross-Cultural Psychology, 18(1), 143-164.

Chow, C., Shields, M., Chan, Y. 1991. The effects of management controls and national culture on manufacturing performance: an experimental investigation. Accounting, Organisations and Society, 16, 209-226.

Cohen, J., Pant, L., Sharp, D. 1995. Culture-based ethical conflicts confronting multinational accounting firms. Accounting Horizons, 7(3), 1-13.

El-Shinnawy, M., Vinze, A. 1997. Technology, culture and persuasiveness: a study of choice-shifts in group settings. International Journal of Human-Computer Studies, 47, 473-496.

Goodwin J., Goodwin D., Fiedler, B. 2000. The influence of culture on accountants' ethical decision making in Singapore and Australia. Accounting Research Journal, 13(2), 22-36.

Grima, S., Seychell, S. and Bezzina, H.F. 2017. Investigating Factors Predicting Derivative Mishandling: A Sociological Perspective. European Research Studies Journal, 20(4A), 3-17.

Harrison, G. 1994. Culture and management. Australian Accountant, 14 -22. 
Hofstede, G.H. 1980. Culture's consequences. Beverly Hills, Sage Publications.

Hofstede, G.H. 1991. Cultures and organizations: software of the mind. New York, McGraw Hill.

Hofstede, G.H., Bond, M.H. 2001. The Confucius connection: from cultural roots to economic growth. Organizational Dynamics 4, 10-521.

Jindrichovska, I. and Kubickova, D. 2016. Perception of Accountants and Accounting Profession in two Countries: Different Terms of Economy and Culture. International Journal of Economics \& Business Administration, 4(3), 60-79.

Johnson, B. 1977. Communication : the process of organization. Boston, MA, Allyn and Bacon, Inc.

Lewis, R.D. 2000. When cultures collide managing successfully across cultures. Naperville, ILL, Brealey Publishing.

McMillan, J., White, R. 1993. Auditors' belief revisions and evidence search: the effect of hypothesis frame, confirmation bias, and professional scepticism. The Accounting Review, 68(3), 443-465.

Mock, T.J., Wright, A. 1993. An exploratory study of auditors' evidential planning judgements. Auditing: A Journal of Practice and Theory, 12(2), 39-61.

Osgood, C.E., Suci, G.J., Tannenbaum, P.N. 1957. The measurement of meaning. Urbana, ILL, University of Illinois Press.

Suryanto, T., Thalassinos, E.J., Thalassinos, I.E. 2017. Board Characteristics, Audit Committee and Audit Quality: The Case of Indonesia. International Journal of Economics \& Business Administration, 5(3), 47-57.

Suryanto, T., Thalassinos, I.E. 2017. Cultural Ethics and Consequences in Whistle-Blowing among Professional Accountants: An Empirical Analysis. Journal of Applied Economic Sciences, 6(52), 1725-1731.

Triandis, H.C., Bontempo, R., Villareal, M. 1988. Individualism and collectivism: crosscultural perspectives on self-ingroups relationships. Journal of Personality and Social Psychology, 54(2), 323-338.

Trotman, K., Yetton, P.W., Zimmer, I.R. 1983. Individual and group judgments of internal control systems. Journal of Accounting Research, 21(1), 286-292.

Tubbs, R.M., Messier, W.F., Knechel, W.R. 1990. Recency effects in the auditors' beliefrevision process. The Accounting Review, 65(2), 452-460. 